\title{
India as a Partner in Triangular Development Cooperation
}

\author{
Sebastian Paulo
}

\subsection{INTRODUCTION}

Triangular cooperation has attracted growing attention as a feature of the current transformations in the global development landscape. The changing role of rising powers and other middle-income countries as development partners has contributed to a growing diversity of development cooperation approaches (Zimmermann and Smith 2011). In this context, triangular cooperation presents opportunities to shape new types of partnerships that create synergies between North-South and South-South cooperation. As a modality to promote knowledge-sharing among developing countries, triangular cooperation has existed for several decades. The 40th anniversary of the Buenos Aires Plan of Action plus $40(\mathrm{BAPA}+40)$, celebrated at the Second HighLevel United Nations Conference on South-South Cooperation in March 2019 , is a reminder of the long history of support for technical cooperation among developing countries. However, the concept has gained additional traction in recent years as transformations in the global development landscape have accelerated and the implementation of the 2030 Agenda for Sustainable Development has been raising new challenges for global collective action.

The debate on the "means of implementation" for the 2030 Agenda refers to triangular cooperation as a modality to achieve the Sustainable Development Goals (SDGs). SDG 17 stresses the role of triangular cooperation for the sharing of knowledge and technology as well as capacity-building

S. Paulo $(\varangle)$

Independent Researcher, Berlin, Germany

e-mail: mail@sebastianpaulo.net

(C) The Author(s) 2021 
(United Nations [UN] 2015a). The Addis Ababa Action Agenda of the Third International Conference on Financing for Development mentions triangular cooperation "as a means of bringing relevant experience and expertise to bear in development cooperation" (UN 2015b). All major international platforms with a mandate to shape international development cooperationthe Global Partnership for Effective Development Cooperation, the United Nations Development Cooperation Forum, and the Development Assistance Committee (DAC) of the Organisation for Economic Co-operation and Development (OECD) - endorse and support triangular cooperation as a complementary modality.

Although understandings and terminologies of triangular cooperation ${ }^{1}$ vary, the concept generally refers to projects and other initiatives that combine the comparative advantages of Northern donors ${ }^{2}$ and providers of SouthSouth cooperation to share knowledge and address challenges among developing countries. Conventional definitions distinguish between the roles of three different types of actors: "pivotal" countries (especially as contributors of knowledge and development experience), "facilitators" (which support cooperation, e.g. through funding and their experience in managing development cooperation), and partner countries (where the results of cooperation are to be achieved) (Organisation for Economic Co-operation and Development [OECD] 2017). The UN, for instance, defines triangular cooperation as "Southern-driven partnerships between two or more developing countries, supported by a developed country (or countries) or multilateral organization(s) to implement development cooperation programs or projects" (UN 2012).

India has often been highlighted as a country that would be particularly suited to act as a pivotal country in triangular partnerships, given the relevance of its development experience. The idea of India assuming the role of pivotal partner has always evoked high expectations of stronger Southern leadership in triangular cooperation. However, the analysis of the growing global practice of triangular cooperation has given little attention to India's role as a partner so far. India's preference for bilateral action within the framework of South-South cooperation has long prevented a stronger engagement in triangular cooperation. However, India's reluctance to participate in this modality has turned into more openness for alternative partnerships. India has shown leadership in shaping UN-managed funds to support South-South cooperation, such as the India, Brazil, and South Africa Facility for Poverty and Hunger Alleviation (IBSA Fund). Moreover, various types of Indian partners have increasingly cooperated with traditional bilateral donors from the OECD/DAC, such as Norway, the United Kingdom (UK), and the United States, to implement projects in Africa and Asia. The Indo-Japanese initiative for an Asia-Africa Growth Corridor (AAGC) shows growing levels of ambition to work in triangular partnerships. Similarly, Indo-French cooperation to set up the International Solar Alliance (ISA) indicates that India's global 
action on development issues is no longer exclusively determined by traditional conceptions of the North-South divide.

This chapter aims to advance the understanding of India's emerging practice of triangular cooperation. ${ }^{3}$ To this end, the chapter provides a systematic overview and discussion of the main types of triangular cooperation in which India has been engaging. First, the chapter outlines the changes in India's position that have enabled India's growing involvement in triangular cooperation. Second, the chapter presents the two main types of triangular cooperation in which Indian participation has been the most visible so far: UN-supported funds and brokering mechanisms promoted by Northern donors. Third, the chapter discusses possible explanations for India's engagement in these types of triangular cooperation against the background of this volume's conceptual framework of contested cooperation. Finally, the chapter advances the argument that the main push of India's growing practice of triangular cooperation is coming in the form of a third type, referred to here as "triangular platforms" and illustrated through the examples of the AAGC, the ISA, and the Global Forum on Cyber Expertise (GFCE).

The chapter argues that India's emerging practice of triangular cooperation does not fit easily with established definitions and concepts. India's special brand of engagement in triangular cooperation has the potential to reshape important aspects of the global architecture of development cooperation and make significant contributions to achieving the SDGs. Accordingly, the Indian experience should inform the analysis and international practice of triangular cooperation more strongly than in the past.

\subsection{India's Changing Position Towards Triangular Cooperation}

India has long been sceptical of triangular cooperation. The analysis of India's position towards this modality should nevertheless acknowledge that triangular cooperation can be said to have been part of the early history of India's development cooperation. Examples of cooperation with industrialised nations in developing countries date back to the 1950s, when India cooperated with the United States in road and telecommunication projects in Nepal (Chaturvedi 2012a, p. 172). In general, however, India has been reluctant to engage with Northern donors in other developing countries throughout a long period of its post-independence history. India's framing of development cooperation in terms of Southern solidarity, non-alignment, and anti-colonialism has largely stood in contrast to engagement in triangular cooperation, at least as far as cooperation with Northern donors is concerned.

India has shaped its identity as a development partner within the framework of South-South cooperation, explicitly distinguishing its approach from Northern donors. Put differently, "Indian policy reflects a lack of comfort with the prevalent DAC narrative" (Mohanty 2016, p. 2). India's self-image as a demand-oriented development partner mirrors its criticism of Northern 
donors, which are seen as inadequately addressing the needs of developing countries, applying conditionality, and reinforcing asymmetric relationships. Thus, triangular cooperation has constituted a certain reputational risk for India's standing as a leader and benign influence in the Global South. This position continues to influence the rhetoric through which India aims to differentiate itself from the "top-down" or prescriptive approaches of Northern donors. Viewed from the conceptual perspective of this volume, India's scepticism towards triangular cooperation can be seen as an expression of contestation of the Northern donor-led architecture of development cooperation. This contestation forms an integral part of the way in which India has been constructing its identity as a development partner.

Given the absence of an explicit policy document for India's development cooperation in general, India's position and approach towards triangular cooperation are not formalised. The principles of South-South cooperation provide the general framework for India's development partnerships, including India's engagement in triangular cooperation (i.e. respect for national sovereignty, national ownership and independence, equality, non-conditionality, noninterference in domestic affairs, and mutual benefit). Chaturvedi (2016, p. 7), for instance, analyses the larger framework of India's development cooperation through the concept of "development compact", which denotes relations between actors of the South based "on the principles that govern SSC [SouthSouth cooperation]". In line with these principles, triangular cooperation should be demand-driven, triggered by specific requests, and decided on a case-by-case basis for sector-specific projects that yield tangible results for partner countries. These elements are, for instance, strongly reflected in the understanding of India's development cooperation in terms of Mohanty's (2016) “mission approach".

In India's engagement as a partner in triangular cooperation, these principles are naturally enshrined in the UN-based funds supported by India. Moreover, official declarations of intent through which India endorses triangular cooperation with partners such as the British Department for International Development (DFID) contain references to compatibility with key principles of South-South cooperation. For example, the India-UK "Statement of Intent on Partnership for Cooperation with Third Countries" emphasises the "wholly demand-driven manner" of cooperation (Ministry of External Affairs India [MEA India] and Department for International Development [DFID] 2015). Overall, India's approach to triangular cooperation remains vague and flexible, implicitly defined based on the main principles of its development cooperation in general.

India's long-standing distance from triangular cooperation reflects the critical view that, in the absence of genuinely Southern-led initiatives, triangular cooperation perpetuates power imbalances and strengthens Northern influence over South-South cooperation (Abdenur and Marques da Fonseca 2013). Given concerns over Northern domination of triangular cooperation, some Southern partners-wary of being "socialised" into existing patterns of 
development cooperation and co-opted as cheap contractors-have remained reluctant partners. According to some observers, such concerns about equal partnership account for the long absence of major Southern players, especially China and India, from triangular cooperation (McEwan and Mawdsley 2012, p. 1198).

The continued evolution of India's position towards triangular cooperation has to be seen in the context of broader foreign policy shifts in the post-Cold War and post-liberalisation period. According to a common interpretation of these shifts, India has been relaxing its emphasis on "idealism" in favour of a more pragmatic approach to using foreign policy in support of its political and economic emergence on the global stage (Mohan 2003). However, critiques of this perspective caution against overstating the pragmatic turn from "Nehruvian" ideals towards economic interest in India's foreign policy. According to this view, India's foreign policy is the result of "incremental shifts [...] that still pay homage to entrenched institutionalized ideas and ideational frameworks" (Miller and Sullivan de Estrada 2017, p. 49). In a similar vein, analysts of India's development cooperation have been pointing out the continued relevance of the discourse of Southern solidarity for India's development partnerships (Harris and Vittorini 2018). India's position on triangular cooperation can therefore be said to be influenced by the two parallel features of increasing pragmatism, which facilitates stronger engagement with Northern donors, and the enduring pertinence of Southern solidarity as an ideational framework, which continues to feed traditional scepticism towards this type of engagement.

India's position on triangular cooperation also needs to be seen in the context of the evolution of its broader development cooperation architecture. In this regard, India has substantially expanded resources and capacity to forge development partnerships. The financial volume of India's development cooperation saw a fivefold increase during the two decades following the end of the Cold War (Mohanty 2016, p. 6). Geographically, India's bilateral development partnerships expanded to comprehensively cover the Global South, going well beyond the traditional focus on South Asia. India's development cooperation has also matured in terms of instruments and modalities. India's “development compact" provides a broad range of tools and instruments for engagement with other developing countries (trade and investment; technology exchange; training, human capacity and skills development (Indian Technical and Economic Cooperation Programme); lines of credit; and grants) (Chaturvedi 2016). Finally, the institutional architecture of India's development partnerships has evolved, leading to the creation of the Development Partnership Administration (DPA) within the Ministry of External Affairs India (MEA India) in 2012 (Chaturvedi 2015). Based on this institutional development, India's capacity to act as a "pivotal" partner in triangular cooperation has been growing. Especially, the focus of India's development cooperation on capacity-building, skills, and human resource development makes India a suitable fit for the activities typically associated with this 
modality. At the same time, the evolution of India's development cooperation has also increased opportunities for bilateral cooperation, which remains India's preferred option under the framework of South-South cooperation.

As a parallel outcome of India's growing global role as a development partner, India has become increasingly active in shaping alternative platforms and partnerships to complement bilateral action. Since the 2000s, India has been actively shaping new groupings such as IBSA and Brazil, Russia, India, China and South Africa (BRICS), and has forged relationships with regional and continental frameworks, for instance in Africa. Increasing engagement in triangular cooperation, which originated during the same time, can be seen as part of this trend towards a diversification of India's engagement to complement bilateral ties.

Overall, India's gradual openness for (or decreasing scepticism against) triangular cooperation has been facilitated by the softening of the reasons that led to India's initial reluctance. In a more heterogeneous Global South, the foundation of the traditional North-South divide has weakened. Becoming a net provider of development cooperation has put India on a more equal footing with Northern donors. Overall, India's stance on triangular cooperation has changed from reluctance to a discreet form of openness:

India should collaborate with and learn from other donor countries; at the same time, the Indian core mission remains unchanged - empowering developing countries under the SSC [South-South cooperation] umbrella, continuing to play the role of a "partner" as opposed to a "donor" in development assistance initiatives. (Mohanty 2016, p. 8)

\subsection{The Practice of India's Engagement in Triangular CoOperation}

Identifying or quantifying India's engagement in triangular cooperation is difficult, as India does not specifically report cooperation under this label. The analysis in this chapter is limited to the most systematic examples of India's engagement in triangular cooperation. The examples highlighted in this chapter can essentially be divided into two main categories: fund mechanisms in the UN system and brokering mechanisms promoted by Northern donors in India, most importantly DFID and the United States Agency for International Development (USAID). The choice of this distinction does not preclude the existence of other, more isolated examples of triangular cooperation that might not fit into these two categories.

\subsubsection{Fund Mechanisms}

India has shown a preference for triangular cooperation with the UN, which it perceives as a neutral partner promoting Southern-led cooperation. UN organisations have increasingly integrated "South-South and Triangular Cooperation" into their mandates. In 1974, the UN General Assembly endorsed 
the creation of a Special Unit for South-South Cooperation within the United Nations Development Programme (UNDP), now renamed the United Nations Office for South-South Cooperation (UNOSSC). Working with these structures, India has shown leadership in the multilateral sphere by shaping funds for triangular cooperation. These funds can also be seen in the context of India's long-standing support for the BAPA+40 process.

One example is the IBSA Fund, which was established in 2004 and became operational in 2006 (IBSA n.d.). The fund has the objective to share experiences from IBSA countries with least-developed countries and post-conflict countries. It emphasises the importance of capacity-building, local procurement, and the use of Southern expertise. India, Brazil, and South Africa each contribute \$1 million per year. Interested governments initiate discussions on projects and can request support with IBSA representatives around the world. Proposals that receive a favourable opinion from one or more of the IBSA Focal Points in the three capitals are forwarded to the IBSA Fund Board of Directors, which meets quarterly to approve projects, monitor implementation, and provide strategic direction. The UNOSSC acts as the fund manager and the secretariat for the Board of Directors. It initiates contact with potential executing agencies and supports implementation.

As an example of a project, the IBSA Fund financed the building of a centre for HIV/AIDS prevention, testing, and treatment in Burundi. Implemented from January 2010 to December 2012, the project had the objective to support government capacity for the implementation of its HIV/AIDS prevention and care strategy, and to improve the provision of healthcare services related to reproductive health, prenatal care, and family planning. The project budget amounted to $\$ 1,145,630$, with project partners being the Ministry of Health; the Society of Women and AIDS in Africa, Burundi; the UNDP, Burundi; and the United Nations Population Fund (UNFPA), Burundi. Overall, the 2018 overview of the IBSA Fund's project portfolio includes 30 completed, ongoing, or recently approved projects (IBSA and United Nations Office for South-South Cooperation [UNOSSC] 2018).

Another example is the India-UN Development Partnership Fund (DPF), launched on 8 June 2017. The DPF supports the 2030 Agenda for Sustainable Development, prioritising poverty reduction and hunger, health, education, and access to clean water and energy. The DPF's objective is to "support Southern-owned and -led, demand-driven, and transformational sustainable development projects across the developing world" (UNOSSC 2017a). It focuses on least-developed countries and Small Island Developing States. The DPF's first project, for instance, deals with improving resilience to natural disasters in seven Pacific small-island states. The UNOSSC acts as the fund's manager and serves as a secretariat for its Board of Directors. In this role, the UNOSSC coordinates the implementation of projects through UN agencies, governments, and other stakeholders in coordination with partner countries. At the launch, India made an initial contribution of \$5 million, which has since 
been increased by an additional pledge for a multi-year contribution of $\$ 100$ million (UN 2018).

The DPF's first project has been dealing with improving resilience to natural disasters in seven Pacific small-island states (UNOSSC 2017b). Another example is the project Reinforce the Resilience of the Vulnerable Populations in the Regions of the Kanem and Lake Chad. The project aims to restore degraded lands and improve water and sanitation. In addition to supporting sanitation infrastructure, the project builds the capacity of local committees for water management, hygiene, and sanitation, including through training in administrative and financial management. It has a budget of $\$ 600,000$ and is implemented by the UNDP and Chad's Ministry of Energy, Water, and Fishing (UNOSSC 2019).

Overall, the two UN-based funds show that India's role in triangular cooperation is not necessarily limited to being a typical pivotal country that provides knowledge and experience. In fact, Indian partners are not mainly involved in the implementation of the projects mentioned in this section. Instead, India has assumed different roles, notably in conceptualising the funds' structures and approaches, and by providing funding.

\subsubsection{Brokering Mechanisms}

The second main form of Indian engagement in triangular cooperation consists in partnerships among actors from India and other developing countries, with Northern donors acting as brokers of knowledge partnerships and other initiatives. As brokers, Northern donor agencies assume roles that can conceptually be understood as a form of "orchestration" (Abbott et al. 2015). The Northern donor agencies do not implement projects directly but enlist (especially non-governmental) partners from India and other developing countries. To this end, they help connect partners from India and other countries with each other and support their cooperation through facilitative measures, including administrative support, expertise, support for capacity development, and funding. Individual examples of this type of engagement by Indian partners can already be found in the early 2000s, when Norway conducted a programme for "Triangular Institutional Cooperation". In this programme, Norway facilitated cooperation between non-governmental organisations from Ethiopia and India to strengthen their capabilities in the management of natural resources in semi-arid areas (Rajasekaran 2006).

More systematic approaches to engaging Indian partners in triangular cooperation have subsequently been emerging as part of UK and US strategies to reduce and phase out traditional aid programmes. India's global development partnerships with the United States and the United Kingdom have been instrumental in shaping a model for Indian engagement in triangular cooperation. Both the United States and the United Kingdom stress India's potential as a source of pro-poor innovations that could be applied to different contexts across the developing world (Mitchell 2011; United States Agency 
for International Development [USAID] n.d.-a). This model focuses on leveraging the strengths of India's diverse landscape of non-state and parastatal actors (private sector, civil society organisations, research institutes, the Exim Bank of India, the Federation of Indian Chambers of Commerce and Industry, etc.) to address development challenges in India and other countries. To this end, DFID and USAID draw on technical assistance to build the capacity of partners in India and other partner countries, and facilitate their relationships.

Triangular cooperation in the India-UK partnership has been implemented in several partner countries in South Asia and Africa, covering a broad range of sectors, including nutrition, health, gender equality, trade and investment, and clean energy. ${ }^{4}$ As an example, the Innovative Ventures and Technology for Development Programme aims to tap the innovative potential of the Indian private sector to make technological and business solutions available to the poor in low-income states in India and other countries. Another example, the Global Research Partnership on Food and Nutrition Security, Health and Women, is designed as a "trilateral collaborative research programme". The programme promotes the generation, testing, and use of research conducted by consortia of institutions from India, the United Kingdom, and developing countries. As a final example, Supporting Indian Trade and Investment for Africa (SITA) is a South-South aid-for-trade and value-chain programme. The programme supports higher-value exports from Ethiopia, Kenya, Rwanda, Tanzania, and Uganda to India and other countries by leveraging Indian know-how, technology, and investment to upgrade exports in partner countries. In international comparison, DFID's triangular programmes with Indian partners stand out, in that they have above average durations (ranging from four to seven years) and higher budgets (from $£ 9$ to $£ 38$ million), when compared to other cases of triangular cooperation (OECD 2017; Paulo 2018).

Triangular cooperation in the framework of the India-US development partnership has been implemented in a growing number of countries in Asia and Africa, for example Afghanistan, Cambodia, Laos, Ghana, Tanzania, and Zambia (USAID n.d.-b). Projects cover food security and nutrition, access to quality health care, women's empowerment, and clean energy. Triangular projects have been implemented, for example, under the US presidential initiative "Feed the Future", in which the United States cooperates with India as a strategic partner. In one example, the Feed the Future India Triangular Training Program, USAID cooperates with the National Institute of Agricultural Extension Management (MANAGE), a research institute affiliated with the Indian Ministry of Agriculture. The project trains agricultural practitioners from 17 countries across Africa and Asia on specialised farming practices to improve productivity and incomes (USAID n.d.-b). Another example is the Global Linkages project that facilitates the sharing of Indian innovations and best practices in family planning as well as child and maternal health care with other countries. As a final example, the United States works with Indian institutions in the South Asia Regional Initiative for Energy Integration to 
promote cross-border electricity trade in South Asia by facilitating energy relations between India and neighbouring countries.

DFID and USAID programmes are often structured around a lead partner that has the required management experience and sector-specific expertise. Examples of lead partners include the International Trade Centre in the case of SITA and MANAGE in the Feed the Future India Triangular Training Program. Lead partners often already have experience in working in other countries and have relevant networks. For instance, the Energy and Resources Institute (TERI) - the lead partner in the completed DFID-TERI Partnership for Clean Energy Access and Improved Policies for Sustainable Development-has a track record and presence in Africa.

Compared to approaches that work through given structures of bilateral cooperation or permanent funds, brokering mechanisms are more flexible. This way of working corresponds to an explorative and demand-searching approach that allows room for innovative ideas. At the same time, brokering mechanisms rely strongly on donor agencies to overcome and manage startup and transaction costs, and to facilitate cooperation as hubs for expertise, knowledge, and partnership-building throughout the duration of programmes (Paulo 2018). This changing profile of requirements has also led to organisational innovations, allowing donor agencies to assume the role of identifying potential areas of cooperation, convening partners, and establishing relationships. The Global Partnership Team in DFID India is an example.

The design of triangular cooperation as brokering mechanisms is also a consequence of large differences in development cooperation approaches between India and Northern partners. As a result, this type of triangular cooperation has remained operationally relatively disconnected from India's and Northern partners' respective bilateral programmes with partner countries. Overall, these brokering mechanisms correspond to what is called a "broad" definition of triangular cooperation. Views differ with regard to how the three main actor types in triangular cooperation ("facilitator", "pivotal country", partner country) should be involved throughout the various phases of cooperation. Some countries and organisations distinguish between "strong" "narrow" and "weak"/"broad" definitions (OECD 2013, p. 14). According to the former, all partners are involved at each step of the project cycle, from planning, financing, and implementation to evaluation. The German Ministry for Economic Cooperation and Development, for instance, defines triangular cooperation as being "jointly planned, financed and implemented" by all partners together (German Ministry for Economic Cooperation and Development 2013). The broader definition, in contrast, is more flexible and can therefore grasp a wider range of examples. From this perspective, actors can have varying degrees of involvement throughout the project or programme cycle (e.g. planning and funding by the Northern donor, implementation by partners from the pivotal and partner countries). 


\subsection{Why Does India Engage in Triangular Cooperation?}

India's motivations for engaging in triangular cooperation cannot be considered separately from determinants of India's development cooperation in general. Throughout different phases of its history, India's development cooperation "has always been driven by a mix of strategic and prestige-related motives" (Mukherjee 2015, p. 180). In addition to Southern solidarity and the desire to acquire international prestige, motivating factors also include a range of economic and political interests (Fuchs and Vadlamannati 2013). Similarly, a mix of all these factors is likely to influence India's engagement in triangular cooperation. For instance, it would be plausible to assume that India's support of UN-based funds is closely related to motives around Southern solidarity, global responsibility, and international prestige (also in view of achieving ambitions such as a permanent seat in the United Nations Security Council).

However, determining the reasons behind India's engagement in triangular cooperation in a more consistent manner is difficult, as this modality is still only a minor aspect of India's role as a global development partner. Referring to the limited role of triangular cooperation in India's development cooperation is not necessarily only a quantitative argument. Triangular cooperation is usually not a dominant expenditure item for any development actor, not even for countries that have a reputation for being highly active users of this modality. A more important impediment to identifying motivating factors is that India has not prominently showcased triangular cooperation as part of its development partnerships until now, at least not when it comes to such partnerships with Northern donors.

Part of the reason why India has been reluctant to engage with Northern donors for so long is a lack of clear incentives. Interestingly, India and China, which both avoided triangular cooperation with Northern donors until recently, are now becoming more active in this modality at the same time. China engages in partnerships with Northern donors to address critical perceptions of its growing external footprint and to demonstrate that it is a reliable international actor willing to learn from other partners (United Nations Development Programme 2016). Mutual learning and assuming growing global responsibilities are equally relevant to India's engagement in triangular cooperation. In view of growing global demands on India as a rising power, cooperation with international partners can help bridge gaps in India's capacity to deliver development partnerships. Observers of India's development cooperation expect "enormous potential gains to be made through improved trilateral donor cooperation" (Chaturvedi 2012b, p. 575). For India, triangular cooperation is therefore an option to satisfy growing demand for cooperation and assume global responsibility without straining the capacity of its own official development partnerships. 
Bolstering capacity to act as a development partner also matters for India in the context of a challenging geopolitical environment. India's recent political endorsement of triangular cooperation correlates closely with China's announcement of the "Belt and Road Initiative" (BRI) in 2013. India is among the most vocal critics of China's flagship infrastructure and connectivity initiative, having raised concerns about the BRI's political and security implications in its neighbourhood (Baruah 2018). Since 2015, India has endorsed triangular cooperation (or references to cooperation in third countries) at the highest political level with partners such as the United States, Japan, the United Kingdom, the European Union, and France. ${ }^{5}$ Moreover, triangular cooperation with the United Kingdom and the United States has acquired a more official dimension through the adoption of guiding documents. The MEA India and USAID signed a "Statement of Guiding Principles on Triangular Cooperation for Global Development" in 2014 (MEA India 2014). Moreover, the US Millennium Challenge Cooperation and the DPA signed a "Joint Statement on Cooperation" in 2017 to strengthen regional integration and connectivity, especially in the areas of energy, trade, and investment (US Millennium Challenge Cooperation and Development Partnership Administration 2017). In 2015, the MEA India and DFID signed the "Statement of Intent on Partnership for Cooperation in Third Countries" (MEA India and DFID 2015). Overall, triangular cooperation has increasingly been integrated as an appendix to broader political, security, and economic relationships with like-minded partners, with China's growing global footprint being a relevant-but not the only-factor in the international context.

Against this background, India aims to construct its own global role by differentiating its approaches from the "top-down" approaches of both Northern donors and China, while at the same time seeking cooperation with both. India's positioning has become more pragmatic, drawing on different partnership geometries depending on the strategic context and the issue concerned. In some cases, India seeks to distance itself from Northern donors by cooperating with China in the BRICS framework, for instance by creating new development finance institutions, such as the New Development Bank and the Asian Infrastructure Investment Bank. At the Wuhan summit in 2017, India and China evoked the possibility of Indo-Chinese triangular cooperation with Afghanistan (Varma 2018). In other cases, India has projected criticism at China that it usually voices against Northern donors. In these cases, India constructs partnerships, including triangular cooperation with Northern donors, to offer developing countries additional options to China's growing global footprint as a development partner.

This fluid positioning between contestation and cooperation raises the question to what extent India's growing engagement in triangular cooperation can be interpreted through this volume's main theme of contested cooperation. Some aspects of India's global engagement, such as the establishment of the New Development Bank and the Asian Infrastructure Investment Bank in the BRICS framework, have already been analysed from similar perspectives, such 
as "contested global governance" (Zürn 2018) or "contested multilateralism" (Morse and Keohane 2014). In a similar vein, India's engagement in triangular cooperation could be considered as a strategy to reshape existing institutions of development cooperation or create new ones. However, as far as the cases of Indian participation in triangular cooperation discussed above are concerned, they do not lend themselves as clear-cut examples of contested cooperation. For instance, India's UN-based triangular funds are clearly not an attempt to challenge the UN. On the contrary, these funds are an expression of India's support for the UN system and a demonstration of its willingness to assume more global responsibility.

In the case of triangular cooperation with Northern donors, India does not yet have a sufficiently strategic approach to be able to draw on triangular cooperation as a means of contested cooperation. In other words, there is no strong evidence to suggest that India actively steers triangular relationships with donors such as USAID or DFID to achieve specific strategic objectives. In the mentioned examples, the Indian government's operational support for the implementation of triangular projects outside of India remains weak, given line ministries' focus on domestic concerns and capacity limitations in the foreign service. As a consequence, the role of Northern donor agencies as brokers of cooperation is still driving these partnerships. Rather than India actively drawing on triangular cooperation to change the norms, ideas, and institutions of development cooperation, Northern donors hope to integrate India into the existing architecture of development cooperation. However, the overall weak government-to-government dimension of this type of triangular cooperation limits influence in both ways. Northern donors do not substantially influence India's development cooperation, nor does India actively use triangular cooperation to challenge and reshape global institutions of development cooperation. In short, triangular cooperation between India and Northern donors has so far had little mutual influence on their approaches to development cooperation.

\subsection{Shaping Narratives and Institutions Through Triangular Platforms}

Although contested cooperation cannot provide a convincing explanation for the current practice of India's engagement in triangular cooperation, it might still help in understanding other innovative aspects of India's cooperation with Northern donor countries. One such aspect is the emergence of larger cooperation frameworks, which will be described here as "triangular platforms", to (re)shape narratives and institutions of global development. Three examples illustrate how India has been initiating or engaging in such platforms: the AAGC, the ISA, and the GFCE.

This chapter uses the term "triangular platform" as an analytical perspective through which important aspects of India's global engagement as a development partner can be understood and interpreted. However, the use of this 
term does not suggest that the examples in this chapter constitute a new empirical reality in global affairs. Nor does the term replace other concepts that already grasp the mentioned examples as empirical phenomena. As an inter-governmental treaty-based organisation headquartered in India, the ISA, for instance, is conceptually already covered as an international organisation. The nature of the GFCE can be understood with concepts such as "multistakeholder partnership" or "polycentric institutions" with the participation of both public and private actors in global governance (e.g. Ostrom 2012). Finally, the AAGC could simply be considered as a bilateral statement of intent between Japan and India. The term "triangular platform" is therefore not necessary to establish the empirical existence of these different examples. However, drawing on this new term-based on the underlying logic of triangular cooperation-highlights certain main characteristics that all these examples have in common.

These platforms share basic characteristics with triangular cooperation, notably the combination of different types of actors. Similar to a conventional understanding of triangular cooperation, triangular platforms combine the comparative advantages of Northern and Southern providers of development cooperation to address challenges in developing countries. They all provide space for collaboration among different actor types, including rising powers, developing and industrialised countries, as well as international organisations and various non-state actors. ${ }^{6}$

With the AAGC, for instance, India and Japan aim to link economies from Asia and Africa through physical infrastructure as well as institutional, regulatory, and digital connectivity (Research and Information System for Developing Countries [RIS] et al. 2017). Combining the comparative advantages of India, Japan, and other international partners, the AAGC aims to facilitate the sharing of development experience among Asian and African countries. Similarly, the ISA was launched under the leadership of India and France. It provides a platform for cooperation to promote the use of solar energy and reduce dependency on fossil fuels in developing countries. The ISA aims to address the particular set of challenges that solar resource-rich countries face with regard to energy access, energy equity, and affordability. To this end, ISA member countries and other stakeholders cooperate on a voluntary basis in programmes and activities that facilitate the use of solar energy, including access to finance, sharing of solar technologies and innovations, research, and capacity-building (International Solar Alliance 2016). Finally, the GFCE is a multi-stakeholder platform for cooperation among countries, international organisations, and private companies to strengthen cyber capacity and expertise globally. In its early phase, the GFCE was strongly driven by European countries, especially the Netherlands. However, India's engagement as a member country, hosting the GFCE in November 2017, has added triangular features to the platform. As such, the platform aims to support developing countries in reaping the benefits of digital development while managing risks related to cyberspace. To this end, the GFCE aims to promote more effective 
international cooperation in the area of cyber capacity-building (Global Forum on Cyber Expertise [GFCE] 2017).

The perspective of triangular platforms constitutes a fundamental change from conventional definitions of triangular cooperation, which focuses on the level of specific projects, programmes, or other activities, especially as a modality for the implementation of development cooperation. In contrast, triangular platforms shift the perspective from implementation to a higher level of analysis. To be sure, the inclusive composition of these platforms beyond traditional North-South divides opens up new space for triangular projects, programmes, or other activities in the traditional sense. However, this is not their main purpose, as their implementation can also be realised through the usual bilateral or multilateral channels. The first initiatives of the ISA, for instance, consisted of an announcement by the Indian government to extend more than $\$ 1$ billion of Indian lines of credit to partner countries; that is, the implementation phase draws on a tool from India's normal bilateral cooperation (MEA India 2018). Such examples raise questions about the relevance of the conventional understanding of triangular cooperation as projects and programmes for India and other developing countries. The specific geometry of triangular cooperation-bringing together diverse actors from the North and the South—can yield more significant opportunities than the limited exchange of knowledge and experiences. Most importantly, these platforms embody an innovative way of shaping policy narratives and institutional frameworks in specific issue areas.

In this sense, triangular platforms can be understood in terms of contested cooperation. However, the target is not the global aid architecture as such. The Delhi Communiqué, agreed at the GFCE meeting in 2017, is instructive in this regard (GFCE 2017). The communiqué, which outlines general principles to enhance cooperation on cyber capacity-building, is one of the rare documents in which India has subscribed to the development effectiveness principles of the Global Partnership for Effective Development Cooperation. Rather than countering the global aid architecture in general, triangular platforms aim to influence issue-specific norms, standards, and institutions in areas such as connectivity, clean energy, and digital development.

The AAGC, for instance, can be understood as an attempt to shape narratives and institutions of connectivity. The global landscape of connectivity is currently strongly influenced by China's important role in this area of cooperation. India has expressed reservations about China's approach to connectivity, especially the BRI, being concerned that such initiatives might unilaterally determine a connectivity model and undercut international standards (Saran 2018). India's criticism is rhetorically mirrored by the AAGC's emphasis on quality infrastructure and people-centred connectivity (RIS et al. 2017). Although the AAGC should not be considered as an effort to compete with China's connectivity initiatives, it represents an attempt to shape a different connectivity paradigm. 
The cases of the ISA and the GFCE illustrate how India and Northern partners shape new institutions in issue areas where the interests and needs of developing countries have so far not been met by the multilateral system. For instance, Northern donors and the global climate regime have yet to live up to their commitments towards the Global South in terms of access to finance and technology transfer for clean energy. The ISA's geographical definition (with a focus on countries located between the Tropic of Cancer and the Tropic of Capricorn) symbolises a re-balancing from Northern countries as the sources of finance and technology, towards developing countries as the sources of the largest growth in demand for energy in the coming decades. The Indian prime minister's description of the ISA as the "OPEC [Organization of the Petroleum Exporting Countries]" of the future underlines the general idea of empowering developing countries to become major actors in the field of clean energy (Mohan 2018).

Finally, India's increasing engagement with the GFCE is shifting global narratives on Internet governance and standards in cyber capacity-building. As a "swing state" in the debate about Internet governance, India rallies with Western partners to support the model of a free and open Internet governed by a multi-stakeholder approach. At the same time, India promotes the right of developing countries to close the digital divide and develop digital economies that leave room for domestically grown digital solutions and are not subject to technological domination from large global companies.

\subsection{ConcLusion}

India's growing presence in triangular cooperation gives new weight to this niche modality of development cooperation. It also opens up opportunities to address global development challenges in new types of partnerships. India's role in triangular cooperation holds the promise of substantially scaling-up knowledge-sharing among developing countries as a contribution to achieving the SDGs.

India's practice also spearheads new trends. The triangular programmes supported by DFID and USAID, for instance, demonstrate innovative approaches to strengthening the role of non-state actors in triangular cooperation. In the case of IBSA and the DPF, India has taken on roles that go far beyond the sharing of knowledge and experience usually associated with pivotal countries by conceptualising Southern-driven funds and providing (co)funding. Overall, however, India's experience does not fit easily with narrow definitions that prevail in the international debate around this modality. In particular, the emergence of triangular platforms in key areas of global development, such as connectivity, clean energy, and digital development, provides larger frameworks for collective action beyond small-scale knowledge-sharing. These innovations challenge existing analytical perspectives on triangular cooperation. 
The Indian experience should therefore inform the theoretical and practical debate on triangular cooperation more strongly. India's long absence from this debate can partly be explained by its reluctance to engage in triangular cooperation. However, Indian experiences also lack visibility in the analysis of triangular cooperation because they are not yet adequately accommodated by existing definitions and concepts. The emerging practice of India's engagement in triangular cooperation cannot be easily grasped by the predominantly technocratic discourse around mechanisms, operational guidelines, etc. India's practice of triangular cooperation calls into question the emphasis on narrow definitions as the "gold standard" for identifying triangular cooperation.

Most importantly, India's experience calls into question the dominant focus on particular models of designing and implementing projects, programmes, and other activities as the central criteria for identifying triangular cooperation. This chapter proposes to include a higher level of analysis on which Northern and Southern partners engage in shaping narratives and institutions of global development. The AAGC, the ISA, and the GFCE illustrate how the rationale of triangular cooperation can be reframed as providing platforms to facilitate the participation of developing countries in creating the global environment on which their development trajectories depend. Implementation under these larger frameworks does not necessarily need to be triangular, and it can be done in the way that is most effective. Being jointly engaged in every single phase of projects or programmes-as per conventional concepts of triangular cooperation - can improve mutual learning and knowledge-sharing. But it is not an end in itself and does not automatically lead to increased ownership of developing countries. Fulfilling the promises of triangular cooperation also depends on the extent to which triangular cooperation facilitates Southern influence on norms, rules, and institutions of global development. Understood in this way, the modality would gain more traction in India and other developing countries.

Finally, this volume's conceptual perspective on cooperation and contestation sheds light on important dynamics behind India's evolving practice of triangular cooperation. India's positioning has become more flexible than in the past, drawing on different partnership geometries, depending on the strategic context and the issues concerned. Triangular cooperation with Northern donors is one element of these dynamics. However, not every aspect of India's engagement in triangular cooperation can be understood through the prism of cooperation and contestation. Above all, India's approach is not yet entirely guided by a strategy, but it still happens largely by default, driven by broader foreign policy shifts, path dependencies, and capacity constraints. However, given India's growing role as a global development actor, there is a strong case for India's foreign policy and development community to adopt a more active stance in leading and shaping triangular cooperation. 


\section{Notes}

1. This chapter uses the term "triangular" synonymous with "trilateral". Although a case can be made for distinguishing the two terms, discussions around terminology are not the main objective of this chapter.

2. This chapter uses the term "Northern donors" to refer to member countries of the OECD/DAC.

3. This chapter builds on Paulo (2018) and research conducted by the author during his stay at the Observer Research Foundation in New Delhi.

4. The examples are based on Paulo (2018) and drawn from the business cases and annual reviews published on the DFID Development Tracker: https://dev tracker.dfid.gov.uk/.

5. See, for instance, India-US Joint Statement "The United States and India: Enduring Global Partners in the 21st Century", Washington DC, 7 June 2016. India-Japan Joint Statement during the state visit of Prime Minister Narendra Modi, Tokyo, 11 November 2016. Joint Statement during the visit of UK Prime Minister Theresa May to India, "Indi a-UK Strategic Partnership Looking Forward to a Renewed Engagement: Vision for the Decade Ahead", New Delhi, 7 November 2016.. Joint Statement of the 14th India-EU Summit, New Delhi, 6 October 2017. India-France Joint Statement during state visit of president of France to India, 10 March 2018.

6 . It could of course be argued that this characteristic is present in most international organisations, such as the UN and the World Trade Organisation, as these organisations also bring together countries of different income levels from the North and the South. However, this chapter uses the term "triangular platforms" for organisations, partnerships, and other initiatives that are (1) not universal (i.e. not covering close to all countries in the world) and (2) co-created or co-shaped by collaboration between a (or several) Northern donor(s) and an (or several) emerging country (countries) with the main objective to support developing countries in a specific issue area.

\section{REFERENCES}

Abbott, K., Genschel, P., Snidal, D., \& Zangl, B. (2015). Orchestration: Global governance through intermediaries. In K. Abbott, P. Genschel, D. Snidal, \& B. Zangl (Eds.), International organizations as orchestrators (pp. 3-36). Cambridge: Cambridge University Press.

Abdenur, A. E., \& Marques da Fonseca, J. M. E. (2013). The North's growing role in South-South cooperation: Keeping the foothold. Third World Quarterly, 34(8), 1475-1491.

Baruah, D. (2018, August). India's answer to the belt and road: A road map for South Asia (Carnegie India Working Paper). Washington, DC: Carnegie Endowment for International Peace.

Chaturvedi, S. (2012a). India's development cooperation: Expressing Southern solidarity. In S. Chaturvedi, T. Fues, \& E. Sidiropoulos (Eds.), Development cooperation and emerging powers: New partners or old patterns? (pp. 169-189). London and New York, NY: Zed Books.

Chaturvedi, S. (2012b). India's development partnership: Key policy shifts and institutional evolution. Cambridge Review of International Affairs, 25(4), 557-577. 
Chaturvedi, S. (2015). The emerging institutional architecture of India's development cooperation. In E. Sidiropoulos, et al. (Eds.), Institutional architecture and development: Responses from emerging powers (pp. 138-154). Johannesburg: South African Institute of International Affairs.

Chaturvedi, S. (2016, June). The development compact: A theoretical construct for South-South cooperation (RIS Discussion Paper \#203). New Delhi: Research and Information System for Developing Countries.

Fuchs, A., \& Vadlamannati, K. C. (2013). The needy donor: An empirical analysis of India's aid motives. World Development, 44(C), 110-128.

German Ministry for Economic Cooperation and Development. (2013). Triangular cooperation in German development cooperation (BMZ Strategy Paper 5/2013e). Bonn: Author.

GFCE (Global Forum on Cyber Expertise). (2017, November 24). Delhi communiqué on a GFCE global agenda for cyber capacity building. https://www.thegfce.com/ binaries/gfce/documents/publications/2017/11/24/delhi-communique/Delhi+ Communiqu\%C3\%A9.pdf.

Harris, D., \& Vittorini, S. (2018). Taking “development cooperation" and SouthSouth discourse seriously: Indian claims and Ghanaian responses. Commonwealth and Comparative Politics, 56(3), 360-378.

IBSA. (n.d.). The IBSA fund. http://www.ibsa-trilateral.org.

IBSA \& UNOSSC (United Nations Office for South-South Cooperation). (2018). 2018 overview of project portfolio. http://www.ibsa-trilateral.org/images/IBSA_F und_Report_2018.pdf.

International Solar Alliance. (2016). Framework agreement on the establishment of the international solar alliance (ISA). http://isolaralliance.org/docs/Framework\%20A greement $\% 20$ of $\% 20$ ISA-English\%20Version.pdf.

McEwan, C., \& Mawdsley, E. (2012). Trilateral development cooperation: Power and politics in emerging aid relationships. Development and Change, 43(6), 1185-1209.

MEA India (Ministry of External Affairs India). (2014, November 3). India and US expand development cooperation in Asia and Africa. https://mea.gov.in/pressreleases.htm?dtl/24184/India+and+US+Expand+Development+Cooperation+in+ Asia+and+Africa.

MEA India. (2018, March 11). List of solar projects under GoI-LOCs for announcement at ISA founding conference. https://mea.gov.in/bilateral-documents.htm?dtl/ 29606/List_of_solar_projects_under_GoILOCs_for_announcement_at_ISA_Fou nding_Conference.

MEA India \& DFID (Department for International Development). (2015, November 10). Statement of intent on partnership for cooperation in third countries. http:// mea.gov.in/Images/pdfl/statemet_2015_11_12.pdf.

Miller, M. C., \& Sullivan de Estrada, K. (2017). Pragmatism in Indian foreign policy: How ideas constrain Modi. International Affairs, 93(1), 27-49.

Mitchell, A. (2011, February 15). Emerging powers and the international development agenda. Transcript of a speech delivered at Chatham House, London. https:// www.chathamhouse.org/sites/default/files/public/Meetings/Meeting\%20Transcr ipts/15021 l mitchell.pdf.

Mohan, R. (2003). Crossing the rubicon: The shaping of India's new foreign policy. New Delhi: Viking.

Mohan, V. (2018, October 3). ISA could replace OPEC as key global energy supplier in future: PM Modi. The Times of India. https://timesofindia.indiatimes.com/ 
india/isa-could-replace-opec-as-key-global-energy-supplier-in-future-pm-modi/art icleshow/66044985.cms.

Mohanty, S. K. (2016). Shaping Indian development cooperation: India's mission approach in a theoretical framework. In S. Chaturvedi \& A. Mulakala (Eds.), India's approach to development cooperation (pp. 1-13). London and New York, NY: Routledge.

Morse, J. C., \& Keohane, R. O. (2014). Contested multilateralism. The Review of International Organizations, 9(4), 385-412.

Mukherjee, R. (2015). India's international development program. In D. M. Malone, R. Mohan, \& S. Raghavan (Eds.), The Oxford handbook of indian foreign policy (pp. 173-187). Oxford: Oxford University Press.

OECD (Organisation for Economic Co-operation and Development). (2013, May). Triangular cooperation: What's the literature telling us? Literature review prepared by the OECD development co-operation directorate. Paris: Author.

OECD. (2017, May). Dispelling the myths of triangular co-operation-Evidence from the 2015 OECD survey on triangular co-operation (OECD Development Policy Papers No. 6). Paris: Author.

Ostrom, E. (2012). Nested externalities and polycentric institutions: Must we wait for global solutions to climate change before taking action at other scales? Economic Theory, 49(2), Special Issue on Economic Theory and the Global Environment, 353-369.

Paulo, S. (2018, March). India as a partner in triangular development cooperation: Prospects for the India-UK partnership for global development (ORF Working Paper). New Delhi: Observer Research Foundation.

Rajasekaran, N. (2006, May). External evaluation of the triangular institutional cooperation II phase 2003-2005. Oslo: Development Fund.

RIS, ERIA, \& IDE-JETRO (Research and Information System for Developing Countries, Economic Research Institute for ASEAN and East Asia, and Institute for Developing Economies/Japan External Trade Organization). (2017, May 22-26). Asia Africa growth corridor: Partnership for sustainable and innovative development. http://www.eria.org/Asia-Africa-Growth-Corridor-Document.pdf.

Saran, S. (2018, April 12). Why regional connectivity in South Asia should be a strategic priority for India. Hindustan Times. https://www.hindustantimes.com/ analysis/why-regional-connectivity-in-south-asia-should-be-a-strategic-priority-forindia/story-F54OnZRLWM22kbr2LmS7BM.html.

UN (United Nations). (2012, May). Framework of operational guidelines on United Nations support to South-South and triangular cooperation SSC/17/3 (2012). Note by the Secretary-General, High-level Committee on South-South Cooperation, 17th session. New York, NY: Author.

UN. (2015a). Transforming our world: The 2030 agenda for sustainable development $(A / R E S / 70 / 1)$. New York, NY: Author.

UN. (2015b). Addis Ababa action agenda of the third international conference on financing for development. Final text of the outcome document, endorsed by the General Assembly in resolution 60/313 on 27 July 2015. https://www.un.org/ esa/ffd/wp-content/uploads/2015/08/AAAA_Outcome.pdf.

UN. (2018, June 8). India-UN fund gets 22 development projects off the ground in first year. https://news.un.org/en/story/2018/06/1011791.

United Nations Development Programme. (2016, August). Trilateral cooperation with China. Sharing China's development experience through innovative partnerships (UNDP Discussion Paper). Beijing: Author. 
UNOSSC (United Nations Office for South-South Cooperation). (2017a, July 14). India intensifies South-South collaboration through the United Nations. https:// www.undp.org/content/undp/en/home/presscenter/pressreleases/2017/07/14/ india-intensifies-south-south-collaboration-through-the-united-nations.html.

UNOSSC. (2017b, October 5). India to support reconstruction and rehabilitation efforts in hurricane affected countries. https://www.unsouthsouth.org/2017/10/ $05 /$ india-to-support-reconstruction-and-rehabilitation-efforts-in-hurricane-affectedcountries/.

UNOSSC. (2019, January 11). India-funded project garners praise for livelihood improvements in Chad. https://www.unsouthsouth.org/2019/01/11/indiafunded-project-garners-praise-for-livelihood-improvements-in-chad/.

US Millennium Challenge Corporation \& Development Partnership Administration. (2017, January 13). Joint statement on cooperation between the millennium challenge corporation of the United States of America and the development partnership administration of the ministry of external affairs of India. https://mea.gov.in/bilateraldocuments.htm?dtl/27937/Joint_Statement_on_Cooperation_between_the_Millen nium_Challenge_Corporation_of_the_United_States_of_America_and_the_Develo pment_Partnership_Administra.

USAID (United States Agency for International Development). (n.d.-a). USAID/India: Country development cooperation strategy 2012-2016. http:// pdf.usaid.gov/pdf_docs/pdacx592.pdf.

USAID. (n.d.-b). US-India triangular cooperation. https://www.usaid.gov/india/usindia-triangular-cooperation.

Varma, K. J. M. (2018, April 28). Wuhan summit: India, China to undertake joint economic project in Afghanistan. LiveMint. https://www.livemint.com/Politics/ ETJ8tht0aj3TOX4ZEX3GyI/Wuhan-summit-India-China-to-undertake-joint-eco nomic-proje.html.

Zimmermann, F., \& Smith, K. (2011). More actors, more money, more ideas for international development co-operation. Journal of International Development, 23(5), $722-738$.

Zürn, M. (2018). Contested global governance. Global Policy, 9(1), 138-145.

Open Access This chapter is licensed under the terms of the Creative Commons Attribution 4.0 International License (http://creativecommons.org/licenses/by/4.0/), which permits use, sharing, adaptation, distribution and reproduction in any medium or format, as long as you give appropriate credit to the original author(s) and the source, provide a link to the Creative Commons license and indicate if changes were made.

The images or other third party material in this chapter are included in the chapter's Creative Commons license, unless indicated otherwise in a credit line to the material. If material is not included in the chapter's Creative Commons license and your intended use is not permitted by statutory regulation or exceeds the permitted use, you will need to obtain permission directly from the copyright holder.

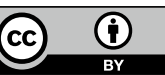

